\title{
局所抗炎症ステロイド剤ハルシノニドの代謝研究
}

\author{
中島栄一, 繁原英治, 堀口正明, 林了三, 田中 実 \\ 三共株式会社 分析代謝研究所 $\bar{\top} 140$ 東京都品川区広町1-2-58 \\ 西垣隆 \\ 三共株式会社 バイオサイエンス研究所 $\mathbf{T} 140$ 東京都品川区広町1-2-58 \\ 宮 腰 永 宏 \\ 三共株式会社 安全性研究所 $\bar{\top} 437$ 静岡県袋井市堀越 717
}

\begin{abstract}
Key word : halcinonide, topical anti-inflammatory steroid, metabolism, autoradiography, rat liver, rat skin, perfusion.
\end{abstract}

\section{Biotransformation of Halcinonide, a Systemic Topical Anti-inflammatory Corticosteroid, in Rat.}
Eiichi' ${ }^{1)}$ Nakajima, Eiji Shigehara, Masaaki Horiguchi Ryozo Hayashi and Minoru Tanaka

Analytical and Metabolic Research Laboratories, SANKYO CO., LTD.

Takashi Nishigaki

Bioscience Research Laboratories, SANKYO CO., LTD.

Nobuhiro Miyakoshi

Laboratory Animal Science \& Toxicology Laboratories, SANKYO CO., LTD

\section{Summary}

Percutaneous absorption and metabolism of halcinonide (21-chloro- $9 \alpha$-fluoro $11 \beta$, $16 \alpha, 17 \alpha$-trihydroxy-4-pregnen-3, 20-dione cyclic-16,17-acetal), a synthetic topical antiinflammatory corticosteroid, were studied in rats with the use of ${ }^{14} \mathrm{C}$-labeled compounds. Greater parts of the dermally applied radioactivity were retained in the skin as the parent compound and 4.2 to $8.4 \%$ of the dose was excreted into urine and feces within 5 days after application. When ${ }^{14} \mathrm{C}$-halcinonide was injected intravenously, the parent compound did not occur in urine and bile. However, various kinds of dechlorinated metabolites were found. Cell-free, skin and liver perfusion experiments were carried out to examine the site of metabolism of halcinonide. In contrast to the low metabolic activity seen in the skin, a very rapid detoxification rate in the liver tissue was observed. From these results, it is suggested that halcinonide is metabolized to various kinds of dechlorinated and reduced metabolites, and disappears from the body rapidly after absorption from the skin. 


\section{緒 言}

Halcinonide (21-chloro-9 $\alpha$-fluoro-11 $\beta, 16 \alpha$, $17 \alpha$-trihydroxy-4-pregnen-3, 20-dione cyclic16，17-acetal）は，皮膚疾患治療剂として開発さ れた合成副腎皮質ステロイドである ${ }^{11}$ 。この化合 物は, 薬理学的検討によって局所抗炎症効果が高 く, 全身性副作用が少ないといら作用の選択性が 示されているが2)，このことが皮膚に塗布後の体 内動態にどのように関連するかを調べるために, ${ }^{14} \mathrm{C}$ で標識したハルシノニドを用いて局所塗布後 の体内動態を調べた.

外用剂の代謝に関する研究は主として製剂学的 に多くの検討がなされているが，皮膚に和ける代 謝および経皮吸収後の動態についての知見は必ず しも多いとは言えない，このことは, 皮覤での代 謝活性が相対的に弱いこととともに吸収後の移行 量が少ないといら困難さによるものと考光られ る.

われわれはまず外用後の動態を調べるととも に, 吸収後の動態を知るモデルとして静注後の動 態を調べ，さらに皮膚灌流法と肝灌流法を用いて 代謝を調べた結果，1）ハルシノニドは皮膚貯留 性が高く，一部は皮膚で代謝されて脱クロール体 を生成する，2）経皮吸収率が低い，3）吸収後 の代謝が速やかであり, 括もに21位 $-\mathrm{COOH}$ 体と して胆汁中に排泄されるといら結果が得られたの で報告する.

\section{1. 実験方法}

\section{1）標識化合物}

(a) ${ }^{14} \mathrm{C}$ 標識 ハルシノニド $\left({ }^{14} \mathrm{C}-\mathrm{HAL}\right.$ と 略す) (Acetone-2-2 ${ }^{14} \mathrm{C}$ 標識 21-chloro-9 9 -fluoro$11 \beta, 16 \alpha, 17 \alpha$-trihydroxy-4-pregnen-3,20-dione cyclic-16, 17-acetal) は, 米国スクイブ社にて合 成されたものを使用した. 方法は 21 位- $\mathrm{OH}$ 体に acetone $-{ }^{14} \mathrm{C}$ を付加させ, このものを $\mathrm{Cl}$ 化する

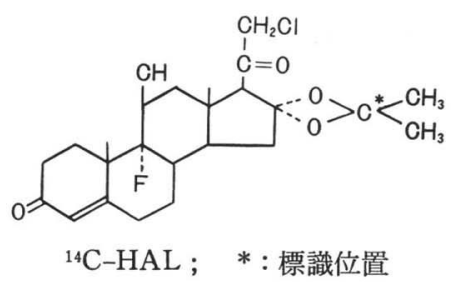

ことによった。

$\mathrm{HAL}$ の化学構造ならびに ${ }^{14} \mathrm{C}$ 標識位置 $(*)$ は, 前図に示す通りである.

比放射能は $12.7 \mu \mathrm{Ci} / \mathrm{mg}$, 放射化学的純度は 98.77\%であった。

(b) ${ }^{14} \mathrm{C}$ 標識 M 1 ( ${ }^{14} \mathrm{C}-\mathrm{M} 1$ と略す) (acetone-2- ${ }^{14} \mathrm{C}$-標識 21 -hydroxy-9 $\alpha$-fluoro- $11 \beta, 16$ $\alpha, 17 \alpha$-trihydroxy-4-pregnen-3, 20-dione cyclic-16, 17-acetal $14.5 \mu \mathrm{Ci} / \mathrm{mg}$ ) は, P. Egli の方 法 ${ }^{3)}$ により ${ }^{14} \mathrm{C}-\mathrm{HAL}$ と同様に調製したものを使 用した。

(c) ${ }^{14} \mathrm{C}$ 標識 $\mathrm{M} 7\left({ }^{14} \mathrm{C}-\mathrm{M} 7\right.$ と略す, 14.6 $\mu \mathrm{Ci} / \mathrm{mg})$ は, ${ }^{14} \mathrm{C}-\mathrm{HAL}$ をラット肝ホモジネート とインキュベートし，TLCにより単離したもの を用いた4).

\section{2）投与薬剤の調製}

\section{(a) 静注用薬剂}

静注実験には ${ }^{14} \mathrm{C}-\mathrm{HAL} 10 \mathrm{mg}$ を $\mathrm{N}, \mathrm{N}$-dimethylacetamide $1 \mathrm{~m} l$ に溶解したものを用いた.

\section{（d）クリームおよび軟膏製剤の調製}

${ }^{14} \mathrm{C}-\mathrm{HAL}$ を含有する軟膏はプラスティベース 85\%，マクロゴール10\%からなる親油性基剤を， クリームはプロピレングリコール $57 \%$, グリセリ ンモノステアレート $13 \%$ を含有する親水性基剤を 用いて作成し， ${ }^{14} \mathrm{C}-\mathrm{HAL}$ の濃度は両剂とも $1 \%$ とした。両剤の比放射能はともに $0.127 \mu \mathrm{Ci} / \mathrm{mg}$ であった。

\section{3）動物実験と投与方法}

\section{(a) 静注実験}

ウイスター今道系ラット, 雄性, 体重約 $200 \mathrm{~g}$ のものを用い, 1 群 3 匹で実験を行った. 投与量 は $5 \mathrm{mg} / \mathrm{kg}$ とし， ${ }^{14} \mathrm{C}-\mathrm{HAL}$ を尾静脈より投与し た後 3 匹を別々の代謝ヶージに入れて96時間飼育 し，その間経時的に尿，粪を採取した，採取した 尿はそれぞれ $50 \%$ のエタノールで 25〜 $50 \mathrm{~m} l$ に希 釈し, その $0.5 \mathrm{ml}$ をとり, 放射能を液体シンチレ ーションカウンターで測定した.

一方, 粪は少量の水を加光約17時間膨潤させた のち, 適当量のエタノールを加光, $50 \%$ エタノー 儿濃度としてポリトロン®破砕器（キネマチカジ ヤパン社）で磨砕抽出した。

\section{(b) 経皮吸収実験}

用いた動物は上記と同じであり， 1 群 3 匹の動 
物を使用した．実験は清水らの手法 ${ }^{5)}$ に準じて行 った、すなわち、ラットは背部の毛をまずハサミ で刈り，次いでエバクレーム®（東京田辺製薬株 式会社）を用いて脱毛した. 薬剤の塗布は ODT 法 (Occlusive Dressing Technique ${ }^{6)}$ ) にしたが い，50 mg の軟高またはクリームを $5 \times 4 \mathrm{~cm}$ の 範囲の皮膚に一様に塗布し, その上から二重のサ ランラップで覆って粘着テープで固定した. 塗布 後に薬剤が経口的に採取されるのを防ぐために， 動物を 1 匹ずつ直ちにボールマンケージに入れ， 飲水, 飼料は自由に採取できるようにして尿䀧を 採取した.

薬剤塗布 24 時間後にサランラップをはがし, 塗 布部位を50\%エタノール綿で 3 回, クロロホルム 綿で 1 回拭いとった.

尿糞の採取は塗布後 5 日間行った.

\section{3）全身オートラジオグラフィ}

（a） 静注実験の使用動物，投与量ならびに投 与方法は, 尿, 粪中排泄実験と同様である. 動物 は投与 $1,3,24$ および 72 時間後に軽くエーテル麻痺 し，ヘキサンードライアイスにて凍結した．以後 は常法にしたがい，クライオミクロトーム（LKB 社）にて $50 \mu$ 厚の凍結乾燥切片を作成した. 切
片をX線フィルム（サクラトリチュームタイプ） に 4 週間露出したのち全身オートラジオグラムを 得た。

（b）軟膏塗布ラットは塗布後 $1,6,24$ 打よび 72 時間目にまたクリーム塗布ラットは塗布後 1 お よび24時間目に, 未吸収薬剂を拭い取った後凍結 した．72時間例については，めらかじめ塗布後 24 時間目に未吸収薬剤を拭い取った。全身オートラ ジオグラムの作成は上記と同様に行い，X線フィ ルムへの露出は38日間とした.

\section{4）皮膚灌流法}

ラットをネンブタール（30 mg/ $\mathrm{kg}$, ip）で麻酔 後, ヘパリンを静脈より投与した。動物を背位に 固定し, 腹部正中線に沿って, 上は頸部, 下は下 腹部まで皮膚を切開した，次に，使用する側の皮 膚を前肢根部の肩甲下動脈を露出するまで剥がし た.上腕動脈, 深在上腕動脈を結禁した後に肩甲 下動脈にカテーテルを挿入し，その動脈が支配す る皮膚の一部約 $5 \times 5 \mathrm{~cm}$ を速やかに摘出し, 直ち に Fig. 1 に示守灌流装置に接続し, 灌流を行っ た、な特，このカテーテルを挿入した肩甲下動脈 から皮膚に分布している血管は，0.25\% Trypan blue を注入することにより確認した.

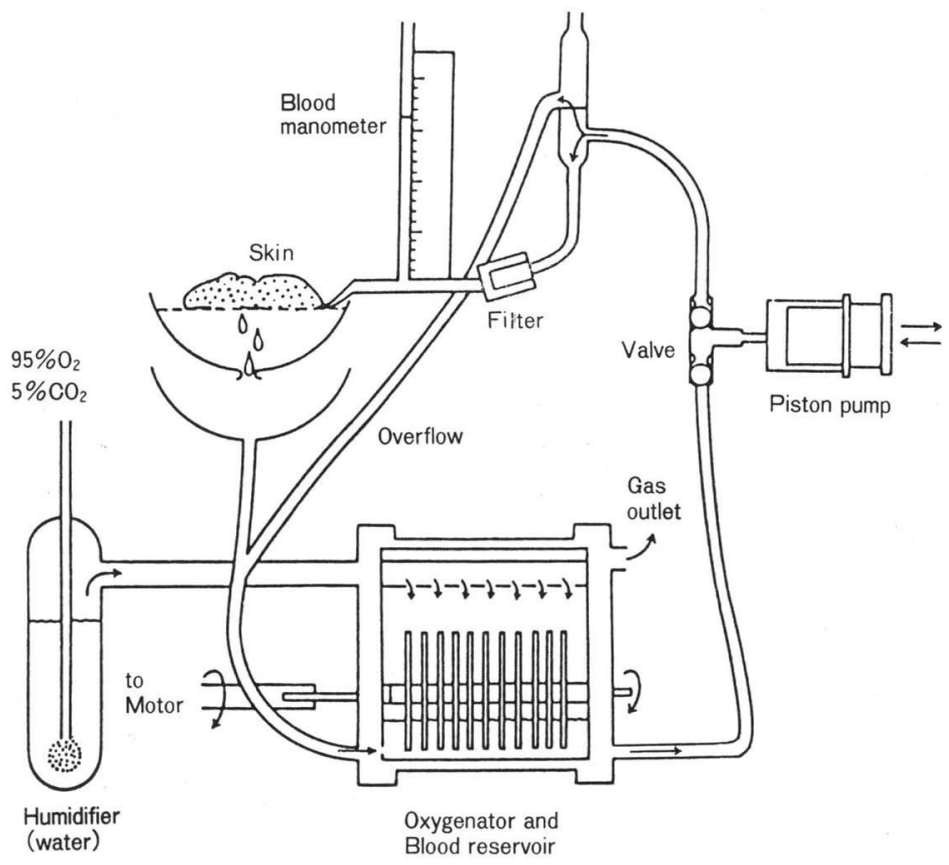

Fig. 1. Schematic Outlook of Skin Perfusion System. 
灌流液の組成は, 同系ラットの新鮮血液 (heparinized) $50 \mathrm{~m} l$ および Krebs-Ringer bicarbonate (pH 7.4) $50 \mathrm{~m} l$ の混合液中に bovine serum albumin $3 \mathrm{~g}$, glucose $150 \mathrm{mg}$ を溶解したものを用 い, $37^{\circ} \mathrm{C}$, 湿度飽和下, 流速 $1 \mathrm{ml} / \mathrm{min}$ で灌流し た.

灌流開始後に ${ }^{14} \mathrm{C}-\mathrm{HAL}$ を灌流液に $1 \mathrm{mg} / 100$ $\mathrm{m} l$ の割合で添加した，灌流終了後，血液に10倍 量のエタノールを加えて遠心分離し, 上清を減圧 下で濃縮して，その一部をTLCにより分離した。 皮膚は水を加兄てポリトロンを用いてホモジナイ ズした。得られたホモジネートに10倍量のエタ， ールを加えた後に遠心分離を行った．上清を濃縮 後，その一部を TLC によって分離した。

\section{5）肝灌流}

ラットを麻酔下に開腹し, ヘパリン静注後, 門 脈と胆管にカニューレを挿入し，直ちに肝臓を摘

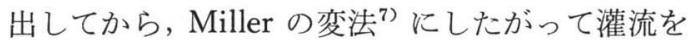
行った.

灌流液の組成は前記の通りである.

\section{6）代謝物の分離之同定}

ウイスター今道系雄性ラット, 体重 $250 \mathrm{~g}$ 前後
に ${ }^{14} \mathrm{C}-\mathrm{HAL}$ または ${ }^{14} \mathrm{C}-\mathrm{M} 1$ を尾静脈注入し，代 謝ヶージに動物を入れて尿を採取した，投与量は $5 \mathrm{mg} / \mathrm{kg}$ である. 尿はXAD-2 カラムでろ過後, メタノールでステロイド化合物を溶出させ，減圧 濃縮後に代謝物をTLC で分離した。

胆汁は，総胆管カニュレーションしたラットに 上記薬物を静注し, 経時的に採取したものを TLC で展開した.

展開液は次の通りである.

プレート: Kiesel gel TLC プレート (Merck, F-254)
A） ベンゼン：エーテル：メタノール $(8: 3: 1)$
B) クロロホルム：アセトン $(1: 1)$
C) ブタノール:酢酸 : 水 $(4: 1: 1)$

上記試料を合成推定代謝物と同時に展開し，そ れぞれのスポットをUV 照射， $\mathrm{I}_{2}$-gas による発 色, Vaniline-硫酸発色, ガスフロー型二次元 TLC スキャナー (Berthold 社)によるアクチグラムな らびにオートラジオグラムなどにより検出, 同定 した。

\section{7）In vitro での代謝}

ラットを断頭放血し，肝臓または皮膚を摘出し

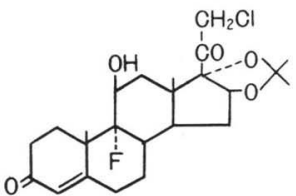

$\underline{\mathrm{HAL}}$

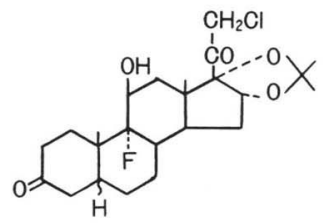

$\underline{\text { M5 }}$

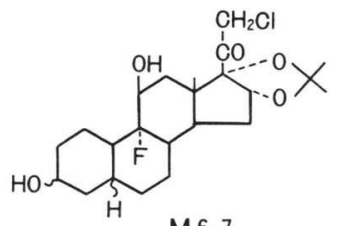

M 6,7

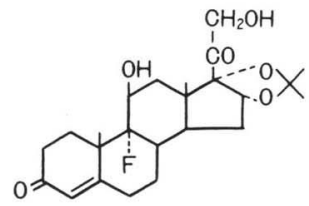

$\underline{\mathrm{MI}}$

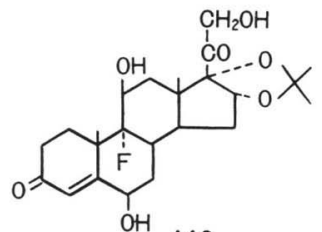

M3

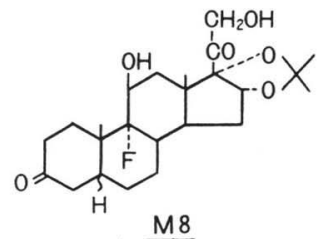

M8

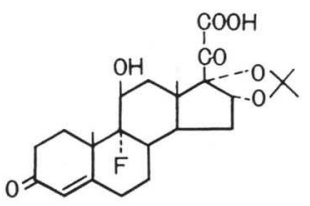

$\mathrm{M} 2$
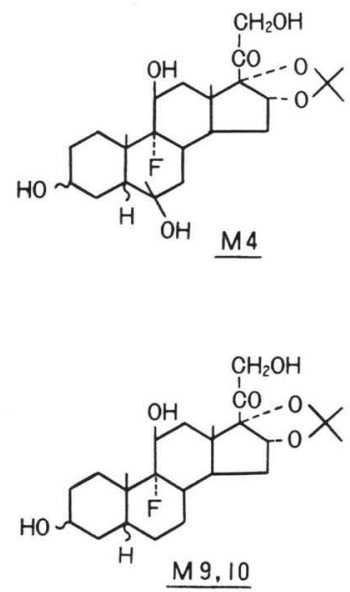

Fig. 2. Chemical Structures of HAL Derivatives. 
た. $1.15 \% \mathrm{KCl}$ 含有 $10 \mathrm{mM}$ phosphate buffer （pH 7.4）を組織湿重量の 3 倍量を加えて常法に よりホモジナイズし, $4{ }^{\circ} \mathrm{C}, 600 \mathrm{~g} \times 20$ 分遠心分 離後の上清を粗酵素液とした. 酵素反応は ${ }^{14} \mathrm{C}$-標 識化合物を最終濃度 $1 \mathrm{mM}$ になるよらに加えて 行った.

生成物は前項の方法にしたがい, 分離同定し た。

一部の代謝物については, 投与後の種々の生体 試料から分離精製し, mass, nmr により構造解析 を行い, 合成代謝物との対比から構造を決定した (木下武, 論文作成中). これらの化合物の構造は Fig. 2 の通りである.

\section{8）放射能の定量}

尿, 胆汁, 組織磨砕液中の放射能は, 一定量を サンプルオギシダイザー (Packard, Model-602) で然焼し, 液体シンチレーションカウンター $(\mathrm{Pa}$. ckard, Model-3255) で測定した.

TLC 上の放射能は, 検出後にシリカゲルをか きとり，バイアルビンに移して上記と同様に放射 能の定量を行った.

\section{2. 実験結果}

\section{1) 吸収と排泄}

\section{(a) 薬物静注投与後の尿, 䔬中排泄}

${ }^{14} \mathrm{C}-\mathrm{HAL} 5 \mathrm{mg} / \mathrm{kg}$ を静注投与後, 経時的に尿, 粪中排泄率を調べた結果を Table I に示した.

糞中に排泄された放射能は, 投与 後 24 時間で $70.9 \% ， 96$ 時間で $89.0 \%$ であった．尿中には24時 間後で $9.2 \%, 96$ 時間後で10.3\%が排泄された.

\section{(b) 薬剤塗布後の尿䔬中排泄}

${ }^{14} \mathrm{C}-\mathrm{HAL}$ を $1 \%$ 含有する軟高就よびクリーム 各 $50 \mathrm{mg}$ を $5 \times 4 \mathrm{~cm}\left(2.5 \mathrm{mg} / \mathrm{cm}^{2}\right)$ に塗布した 後の尿翼中排泄率を調べた. クリームでは塗布後 24 時間で尿中に $0.3 \%$, 粪中に $1.3 \%$ か，また 3 日 間ではそれぞれ0.4\%，3.4\%が排泄された．5日 間の尿粪中排泄の合計は $4.2 \%$ (尿: $0.5 \%$, 粪 : 3.7\%)であった.

一方, 軟膏では塗布後 24 時間で尿中に $0.5 \%$, 糞中に $1.5 \%$ が，3 日間後では各 $1.5 \%, 5.7 \%$ が 排泄された。 5 日間に尿糞中に排泄された合計は 8.4\%（尿: $1.8 \%$, 粪: $6.7 \%$ ) であり, リーム の約 2 倍であった.
Table I Urinary and Fecal Excretion of Radioactivity after Intravenous Administration $(5 \mathrm{mg} / \mathrm{kg})$ of ${ }^{14} \mathrm{C}-\mathrm{HAL}$ to Rats.

\begin{tabular}{ccrr}
\hline \hline & \multicolumn{3}{c}{$\%$ of dose } \\
\cline { 2 - 4 } hrs & urine & \multicolumn{1}{c}{ feces } & \multicolumn{1}{c}{ total } \\
\hline $0-6$ & $4.8 \pm 0.85^{*}$ & - & $4.79 \pm 0.85$ \\
$6-24$ & $4.4 \pm 0.43$ & $70.9 \pm 3.38$ & $75.2 \pm 3.50$ \\
$24-48$ & $1.2 \pm 0.24$ & $12.3 \pm 3.10$ & $13.1 \pm 3.50$ \\
$48-72$ & $0.3 \pm 0.02$ & $5.2 \pm 0.67$ & $5.5 \pm 0.68$ \\
$72-96$ & $0.1 \pm 0.04$ & $0.7 \pm 0.70$ & $0.9 \pm 0.84$ \\
\hline $0-96$ & $10.3 \pm 1.69$ & $89.0 \pm 2.30$ & $99.6 \pm 0.91$ \\
\hline
\end{tabular}

*: Mean value \pm S.E.

\section{2）体内分布}

\section{(a) ラット静注投与後の全身オートラジオグ ラフィ}

雄性 ラット静注投与後の 全身分布を Fig. 3-6 に示した.

静注投与後 1 時間 (Fig. 3) では, 最も高い放 射能は胃腸管内容物に見られ, 組織では肝臓, 八 一ダー氏腺にかなり高い放射能が観察され, 次い で副腎皮質, 腎蔵, 褐色脂肪にやや低い放射能が 示された.

皮下脂肪, 腹部白色脂肪の放射能濃度は褐色脂 肪よりやや低かった，心筋の濃度も同程度であっ た。また, 骨髄, 骨格筋, 血液, 肺, 脾臓, 胃腸 壁などに低い放射能が見られた. 大脳などの中枢 神経系組織にも低濃度ながら放射能が検出され た。

静注投与後 3 時間 (Fig. 4) では, 胃腸管内容 物に最も高い放射能がみられ, 次いで肝蔵が高か った. 脂肪組織（褐色, 白色, 皮下), ハーダー 氏腺に低い放射能がみられ, 腎臓, 副腎皮質, 心 筋の濃度がそれらに続き, 骨格筋, 血液, 中枢神 経系, 胸腺, 肺などの放射能濃度はきわめて低か った.

投与24時間後 (Fig. 5) では, 依然として胃腸 管内容物に高い放射能が観察された。 その他, 副 腎皮質, 肝臓, ハーダー氏腺にかなり低い濃度が 見られ, 褐色脂肪ではきわめて低い放射能濃度が 観察されるのみであった．上記以外の組織からは 放射能は消失していた。

投与72時間後 (Fig. 6) では, 依然として胃腸管 


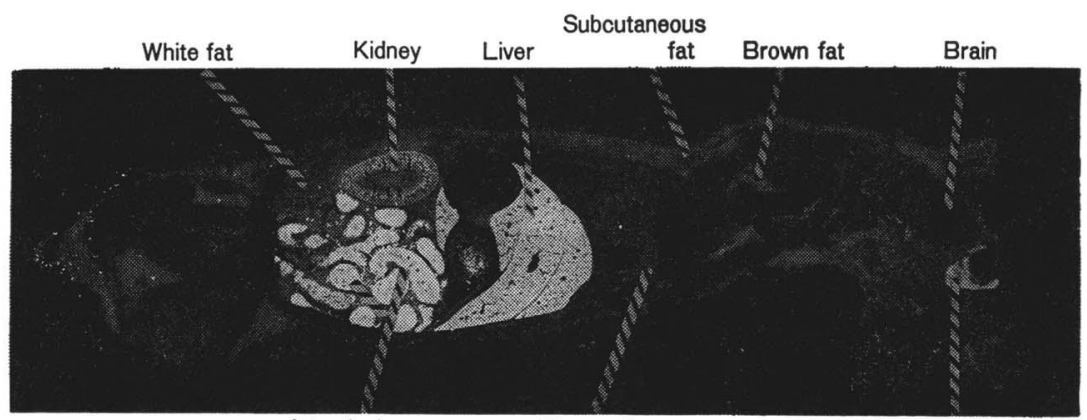

Intestinal

Myocardium

Harderian gland

contents

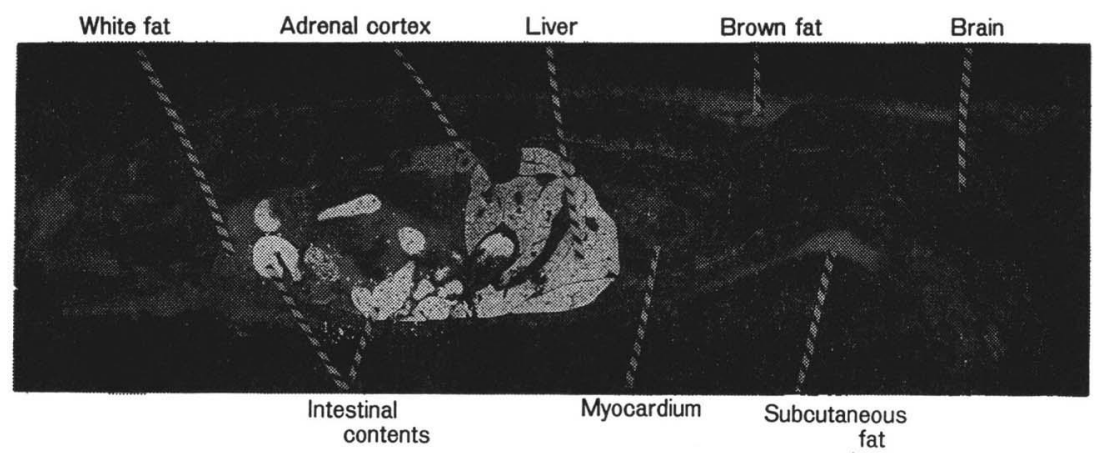

Fig. 3. Whole-body Autoradiograms from the Rat at $1 \mathrm{hr}$ after Intravenous Administration of ${ }^{14} \mathrm{C}-\mathrm{HAL}$.

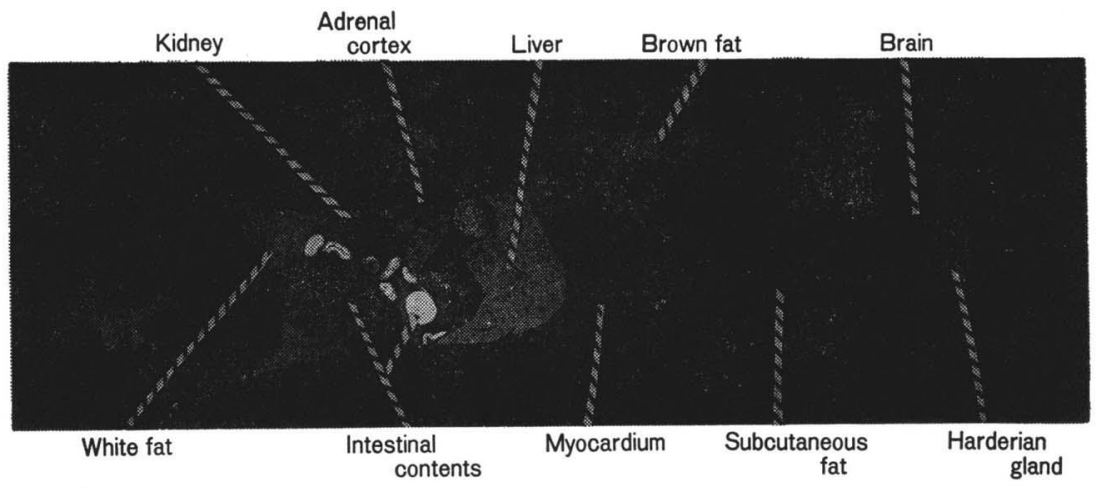

Fig. 4. Whole-body Autoradiogram from the Rat at 3 hrs after Intravenous Administration of ${ }^{14} \mathrm{C}-\mathrm{HAL}$.

内容物にわずかな放射能を認めるのみで，その他 の組織の放射能は消失し, 検出されなかった.

\section{(b) ラット経皮投与後の全身オートラジオグ} ラフィ

${ }^{14} \mathrm{C}-\mathrm{HAL} 1 \%$ 含有クリームおよび軟膏をラッ ト皮膚に塗布したときの全身オートラジオグラム を Fig. 7-10 に示した.

塗布 1 時間後では, Fig. 7 に示すように, 健常
皮膚に塗布した場合，クリーム，軟膏共に塗布部 位に高い放射能が認められた。両剤とも実質組織 中に放射能は検出されず，わずかな放射能濃度が 胃腸管内容物に認められるのみであった。

塗布 6 時間後に拈いても(Fig. 8), 軟高を狳布 したものでは最も高い放射能が塗布部位で見ら れ，胃腸管内容物にやや高い放射能が観察され た. 実質組織では肝蔵に痕跡程度の放射能が認め 


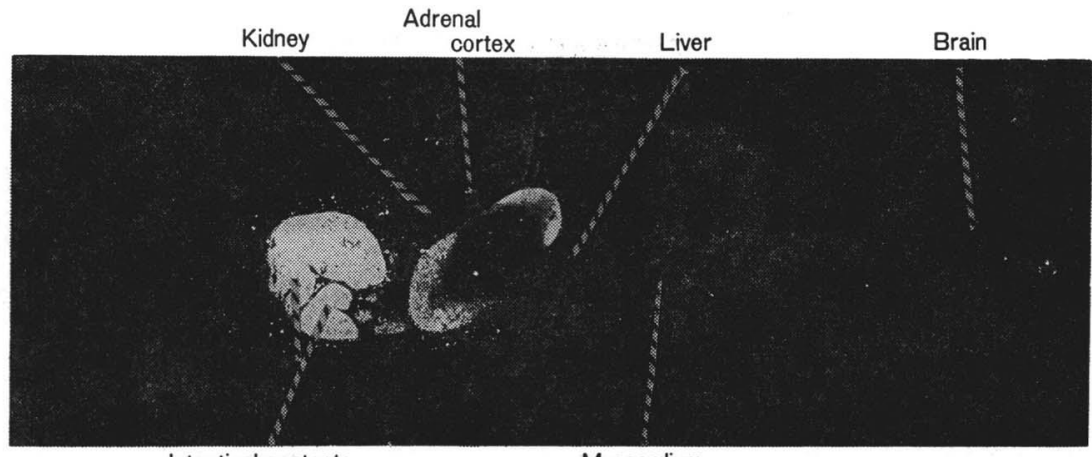

Intestinal contents

Myocardium

Fig. 5. Whole-body Autoradiogram from $\llbracket$ the Rat at $24 \mathrm{hrs}$ after Intravenous Administration of ${ }^{14} \mathrm{C}-\mathrm{HAL}$.

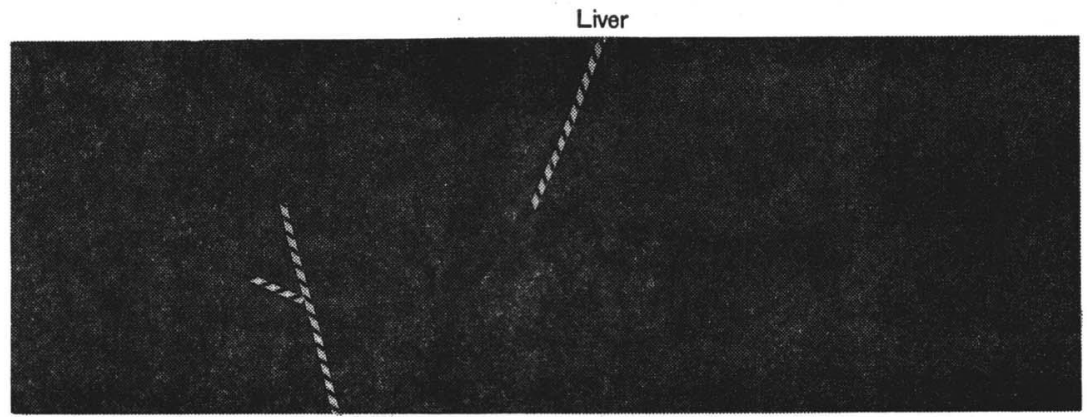

Intestinal contents

Fig. 6. Whole-body Autoradiogram from the Rat at $72 \mathrm{hrs}$ after Intravenous Administration of ${ }^{14} \mathrm{C}-\mathrm{HAL}$.

A

Application site

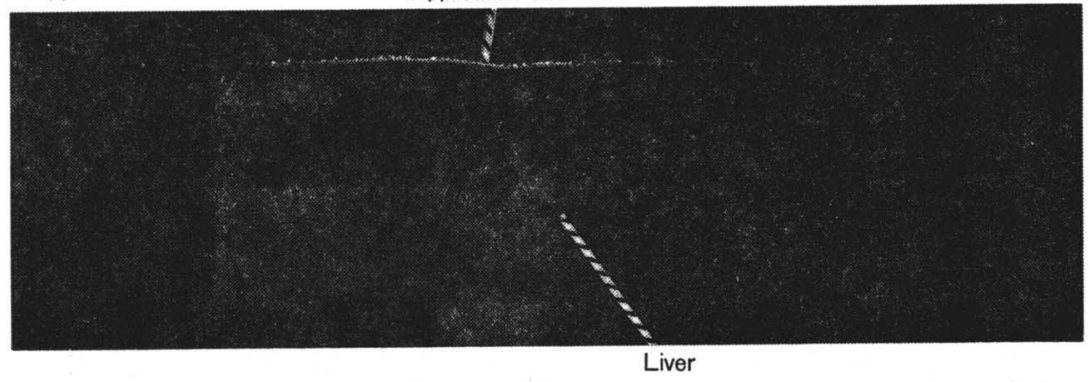

Application site

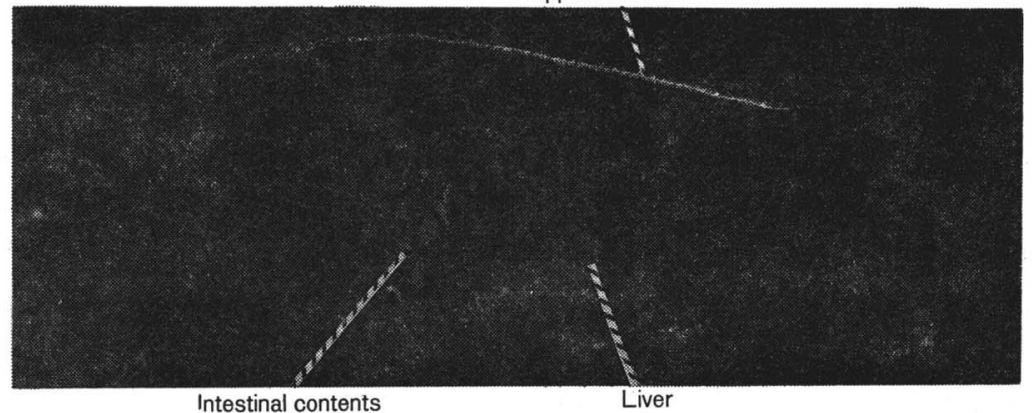

Fig. 7. Whole-body Autoradiogram from the Rat at $1 \mathrm{hr}$ after Topical Application of ${ }^{14} \mathrm{C}-\mathrm{HAL}$. A : cream, B : ointment. 


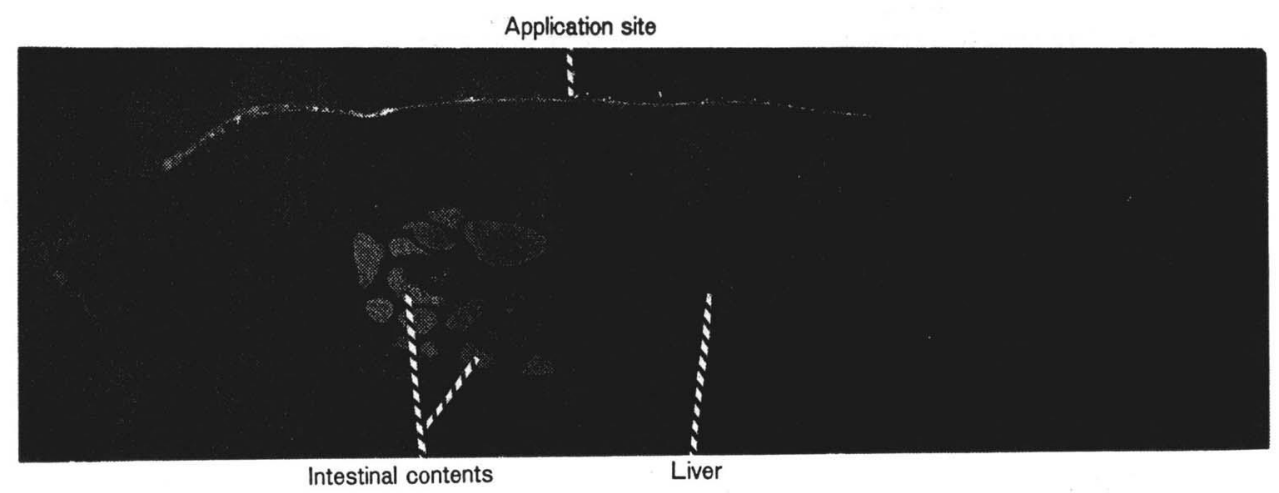

Fig. 8. Whole-body Autoradiogram from the Rat at 6 hrs after Topical Application of ${ }^{14} \mathrm{C}-\mathrm{HAL}$-ointment.

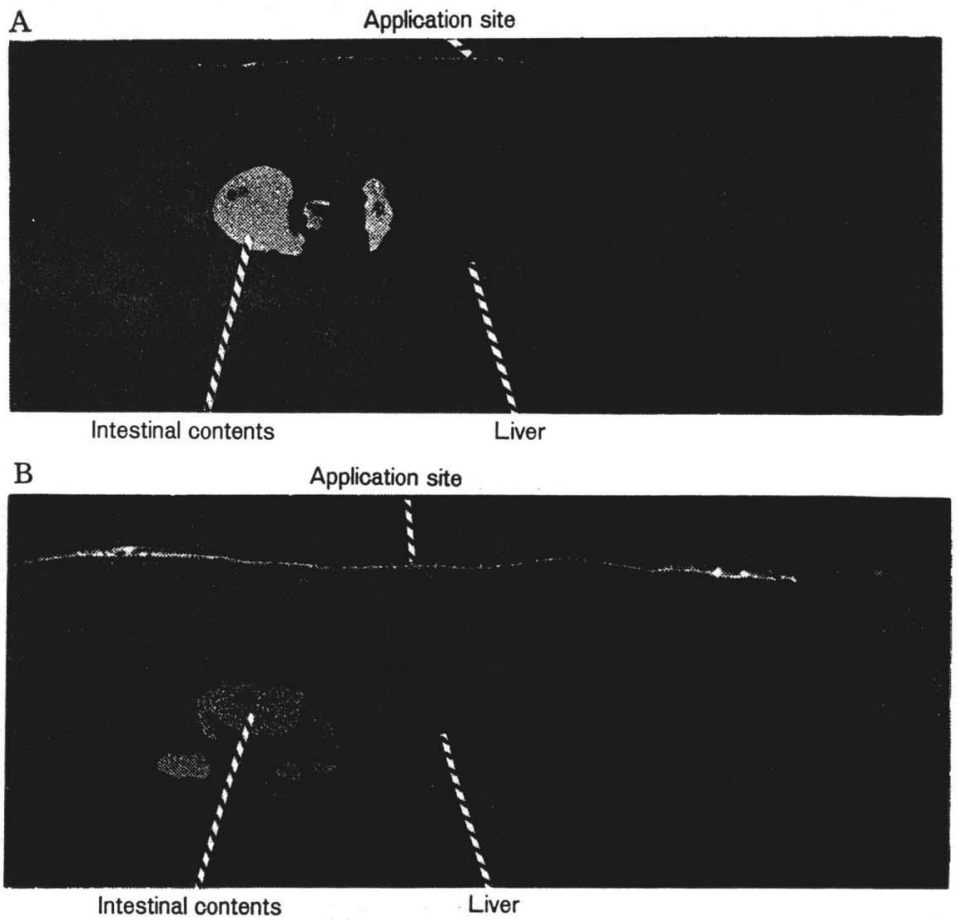

Fig. 9. Whole-body Autoradiogram from Rats at 24 hrs after Topical Application of ${ }^{14} \mathrm{C}-\mathrm{HAL}$. A : cream, B : ointment.

られたのみで，それ以外の組織からは検出されな かった.

両剤塗布後24時間 (Fig. 9), 軟亳除去後48時間 （塗布後72時間，Fig. 10）に拈いて，いずれも塗 布部位に最も高い放射能が，また腸管内容物にや や高い放射能が観察された。しかし，両剂とも塗 布24時間では実質組織中に放射能は認められなか った。

\section{3）静注時の胆汁中および尿中代謝物}

\section{(a) 胆汁中代謝物}

${ }^{14} \mathrm{C}-\mathrm{HAL}$ 静注投与後の 放射能の主排泄経路は 粪中であり, 大部分が胆汁中への排泄に由来して いることが推測されたので, 総胆管カニュレーシ ョンを施したラットに ${ }^{14} \mathrm{C}-\mathrm{HAL}$ を静注し, 胆汁 を採取して代謝物を検索した。

展開した TLC のアクチグラムを Fig. 11 に例 


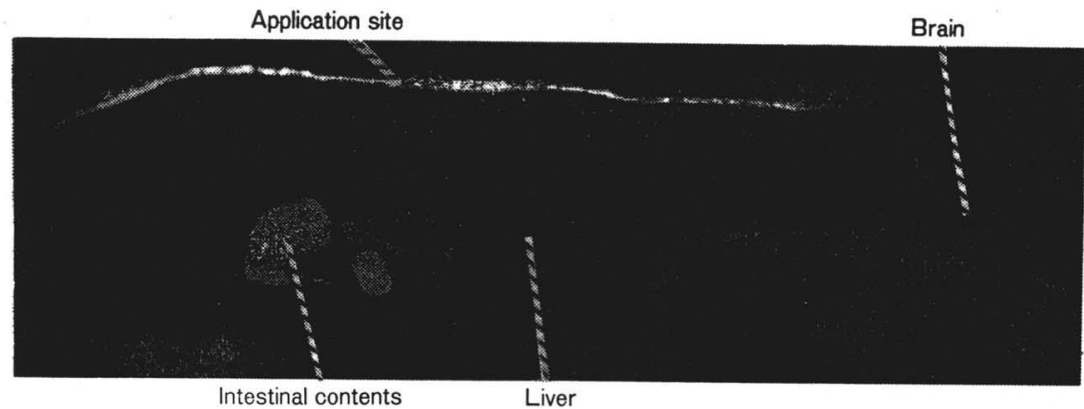

Fig. 10. Whole-body Autoradiogram from the Rat at 48 hrs after ${ }^{14} \mathrm{C}-\mathrm{HAL}$-cream Applied Topically for $24 \mathrm{hrs}$.

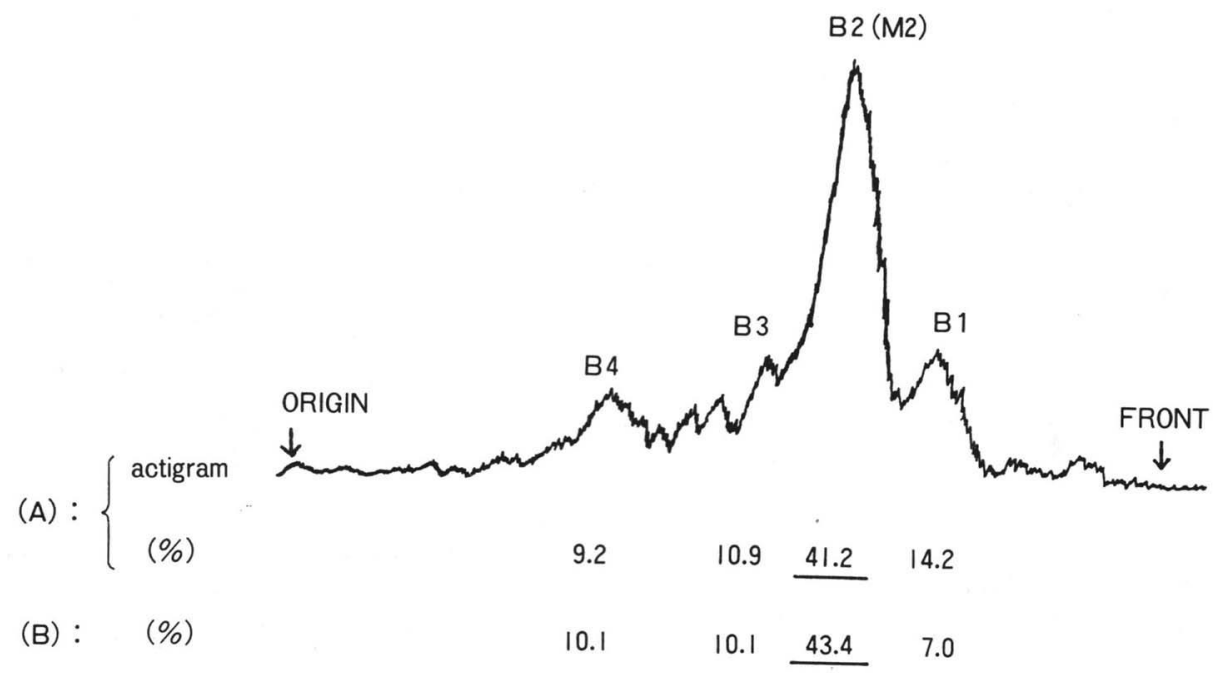

Fig. 11. Contents of Metabolites in Bile after Intravenous Administration of ${ }^{14} \mathrm{C}-\mathrm{HAL}$ (A) or ${ }^{14} \mathrm{C}-\mathrm{Ml}$ (B) to Rats.

Dose : $5 \mathrm{mg} / \mathrm{kg}$, Sampling time : 0-60 min., TLC solvent system : C

示した.オートラジオグラムあるいはアクチグラ ムから, 主代謝物 B2 と, その他の B1， B3， B 4 などの微量代謝物が検出され, B2 成分は胆 汁中で約 $40 \%$ を占めていた。このものは合成品と の cochromatography によって, M2すなわち21 位〜 $\mathrm{COOH}$ 体（Fig. 2 参照）と一致した. また HAL およびM1などの極性の低い代謝物は検出 されなかった。このパターンは，投与初期でも 24 時間後でも変わって拈らず，したがって肝蔵での 代謝は速やかに進み, 生成物は効率良く胆汁中に 排泄されることが示唆された.

さらに, HAL からM2への代謝は, 中間体とし て21位〜 OH 体（すなわち M 1, Fig. 2 参照） を経由すると考えられることから，M1 の ${ }^{14} \mathrm{C}-$
標識体をラットに静注 $(5 \mathrm{mg} / \mathrm{kg})$ して, 胆汁中 代謝物を分離したところ，Fig. 11 に示したよら に43\%の B 2 の生成が見られ, TLC のパターン は ${ }^{14} \mathrm{C}-\mathrm{HAL}$ 静注の場合ときわめて類似したもの であった。

\section{（b）尿中代謝物}

${ }^{14} \mathrm{C}-\mathrm{HAL}$ 静注 $(5 \mathrm{mg} / \mathrm{kg})$ 後 24 時間の尿中には HAL そのものは検出されず, 主代謝物として UA, UB および UC 並びに原点物質が検出され た (Table II). これらは ${ }^{14} \mathrm{C}-\mathrm{M} 1$ を投与しても 同様に生成されたことから，いずれも 21 位にC1 基を持たない代謝物であると推定された。

これらの構造を解析するために，ラット50匹の 尿から分離精製した試料を用いて, 合成標品とと 
Table II Contents of Metabolites in Urine within $24 \mathrm{hrs}$ after Intravenous Administration $(5 \mathrm{mg} / \mathrm{kg})$ of ${ }^{14} \mathrm{C}-\mathrm{HAL}$ or ${ }^{14} \mathrm{C}-\mathrm{Ml}$ to Rats.

\begin{tabular}{ccccccc}
\hline \hline & \multicolumn{5}{c}{$\%$ in urinary radioactivity } \\
\cline { 2 - 7 }${ }^{14} \mathrm{C}$-compound given & origin & UC & UB (M 4) & UA (M 3) & M 1 & HAL \\
\hline Rf-values & 0.0 & 0.26 & 0.35 & 0.39 & 0.44 & 0.69 \\
HAL-14 & 21.6 & 44.8 & 8.4 & 20.7 & 2.1 & n.d. \\
M1- ${ }^{14} \mathrm{C}$ & 18.1 & 41.9 & 4.5 & 25.5 & 5.5 & - \\
\hline
\end{tabular}

TLC solvent system : A
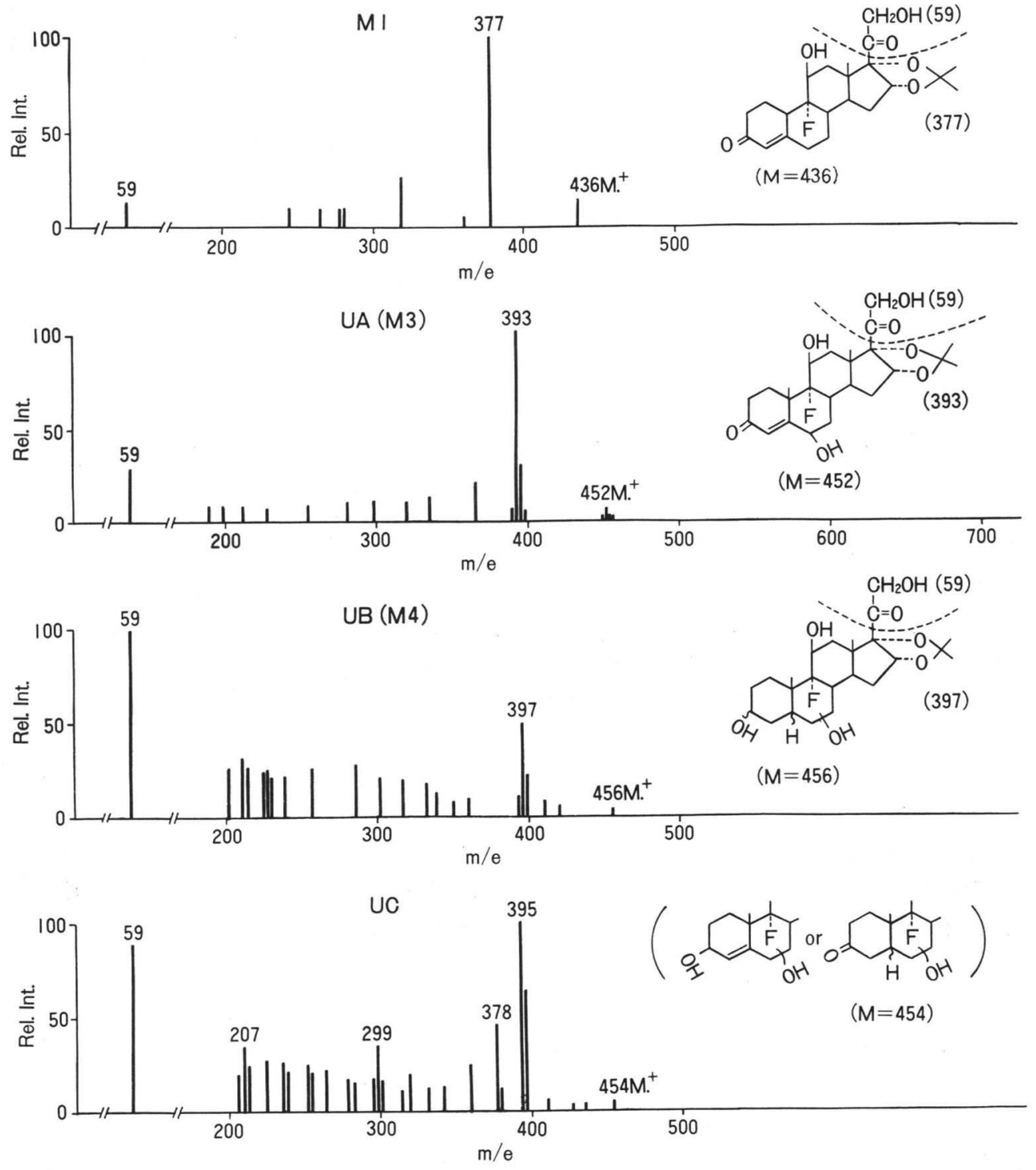

Fig. 12. Mass Spectra of Metabolites of HAL. 
もに mass で分析, 同定した. その結果, UA は M3, すなわち 6- $\beta$-hydroxy-M 1, UB は M4 (Fig. 2 参照) と同定された.

UC は尿中の主代謝物であるが，いずれの合成 標品とも TLC 上で一致しなかった。このものの スペクトルを Fig. 12 に示す. 17位側鎖が59マス であることは20位ヶト基が還元されていないこと を示す、M4のスペクトルと比較すると，UC は 3 位ケト基または $\Delta^{4}$ のいずれかの還元体である と思われるが，後に述べる ${ }^{14} \mathrm{C}-\mathrm{M} 7$ を基質とした 肝灌流で UC が生成されないこと，拈よび6位の $\mathrm{OH}$ 基が $\Delta^{4}$-リダクターゼの結合を立体的に阻害 することがある ${ }^{8)}$ などの理由により，3位ヶト基 側が還元されたものではないかと考えている.

\section{4）皮膚における代謝物}

\section{(a) In vivo での代謝}

${ }^{14} \mathrm{C}-\mathrm{HAL}$ 軟膏約 $50 \mathrm{mg}$ (HAL として $2.5 \mathrm{mg} /$ $\mathrm{kg}$ ）塗布後 2 時間および24時間の皮膚からの未吸 収薬剂を除去後, 皮膚を摘出した。 その皮膚を水 でホモジナイズし, 次にェタノールで抽出, 濃縮 後に TLC で代謝物を分離した.

その結果 Fig. 13 に示したように, 大量の HAL とともに少量の代謝物が検出され, これは合成標 品 M1 と TLC 上の挙動が一致したので21位$\mathrm{OH}$ 体であると判断した.

\section{（b）In vitro での代謝}

皮膚ホモジネートとインキュベートした結果, ${ }^{14} \mathrm{C}-\mathrm{HAL}$ 以外の代謝物は検出されなかった.

\section{（c）皮膚灌流での代謝}

前記の手術法および装置で皮膚を灌流し, HAL の代謝に関する皮膚組織の寄与を検討した。

肩甲下動脈によって支配されている皮膚内の血 管分布を調べるために, 上腕動脈および深在上腕 動脈を結禁後に肩甲下動脈より Trypan blue を 注入した時の写真を Fig. 14 に示した. 写真から 明らかなように, 色素は速やかに皮膚組織にのみ 拡散した。この最も良く染色された部位を $5 \times 5$ $\mathrm{cm}$ の大きさで摘出し, 皮膚灌流系を用い, $\mathrm{HAL}$ $1 \mathrm{mg}$ を灌流液に加兄, 1 時間灌流を行った. 次 いで全灌流血液と皮膚とを摘出し，それぞれの代 謝物をTLC で分離したもののオートラジオグラ ムを Fig. 15 に示した.

その結果, 灌流液中には大量の HAL が認めら れ, M1 の生成はきわめて少なかったが, 皮膚組 織では大量の $\mathrm{HAL}$ ともに, 明らかにM1が生 成されていることが確認された.

5）肝臓における代謝

\section{(a) In vitro での代謝}

${ }^{14} \mathrm{C}-\mathrm{HAL}$ あるいは ${ }^{14} \mathrm{C}-\mathrm{M} 1$ を肝臓のホモジネ ートとインキュベートし，生成した代謝物のアク チグラムを Fig. 16 に示した. HAL を基質にし

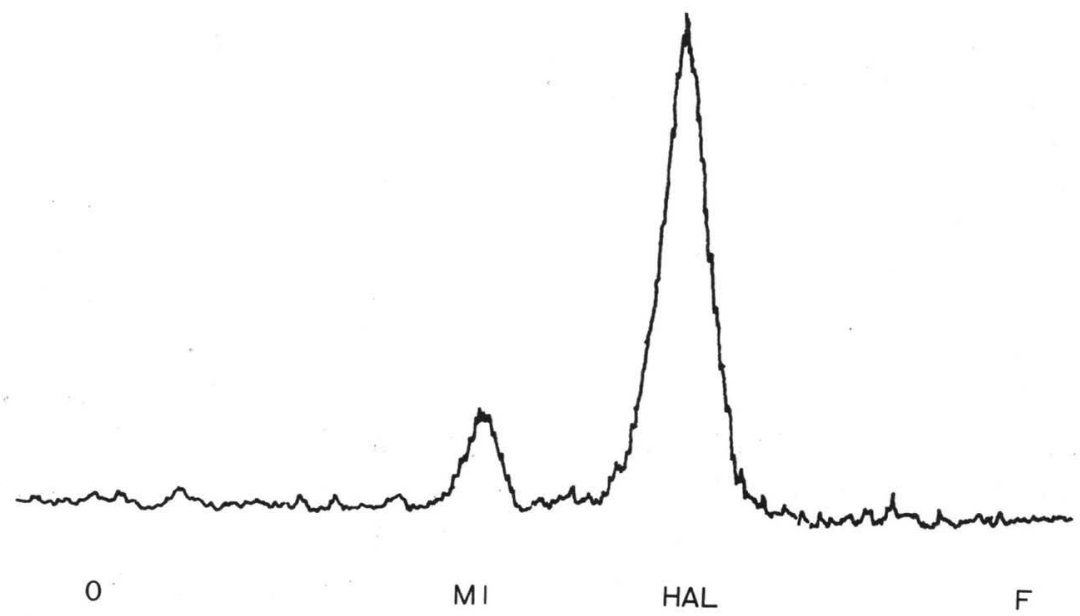

Fig. 13. Actigram of Metabolites in Skin 2 hrs after Percutaneous Administration of ${ }^{14} \mathrm{C}-\mathrm{HAL}$ to the Rat.

TLC solvent system : A 

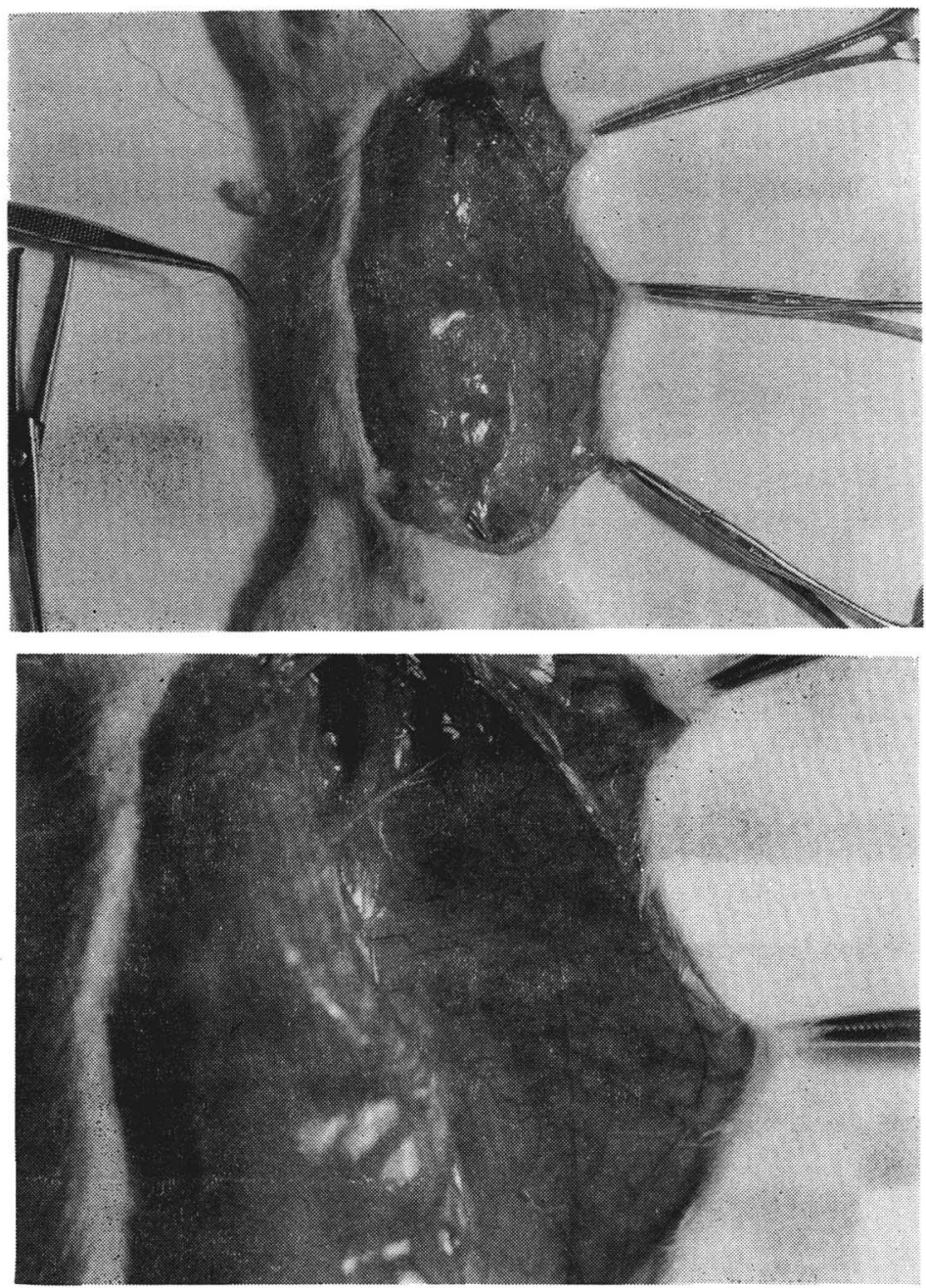

Fig. 14. Distribution of Subscapular Artery in the Skin after Perfusion with $0.025 \%$ Trypan Blue.

た場合には, HALは速やかに減少する傾向（反応 開始後 $10 \mathrm{~min}$ で50\%以下）を示し，M5，M6お。 よび M 7 (Fig. 2 参照) が生成した. 三者共に $\Delta^{4}$ の二重結合を示す UV 吸収 (2537 ̊) は消失 していた.これらを同定するために，大量の肝ホ モジネートで非放射性 HAL より M 5，M 6 およ びM 7 を単離し, gc-mass, nmr 特よび ir などで 分析した結果，いずれも 21 位に $\mathrm{Cl}$ 基を有する還元 体であることが示され， $\Delta^{4}$ 二重結合を示す吸収 の消失が nmrでも確認された. M5 の分子イオン $(\mathrm{M}+)$ は HAL に比べて 2 多く, $\Delta^{4}$ ジヒドロ体 であると結論され，また M6，M7 は M+が共に
458であり， $\Delta^{4}$ および 3 位ケト基が還元されたテ トラヒドロ体の二種の異性体であると推定され た、これらは合成標品との co-chromatography によっても確認された。

一方，M1を基質にした場合には，HAL の場 合と同様に三種の主代謝物を生じ，これらは合成 標品との co-chromatography により， M1 の $\Delta^{4}$ ジヒドロ体（M8）ならびに, M1 の 3 位ヶト 基および $\Delta^{4}$-テトラヒドロ体の二種の異性体（M 9 および M 10, Fig. 2 参照）であると推定され た。 
A

(Blood)

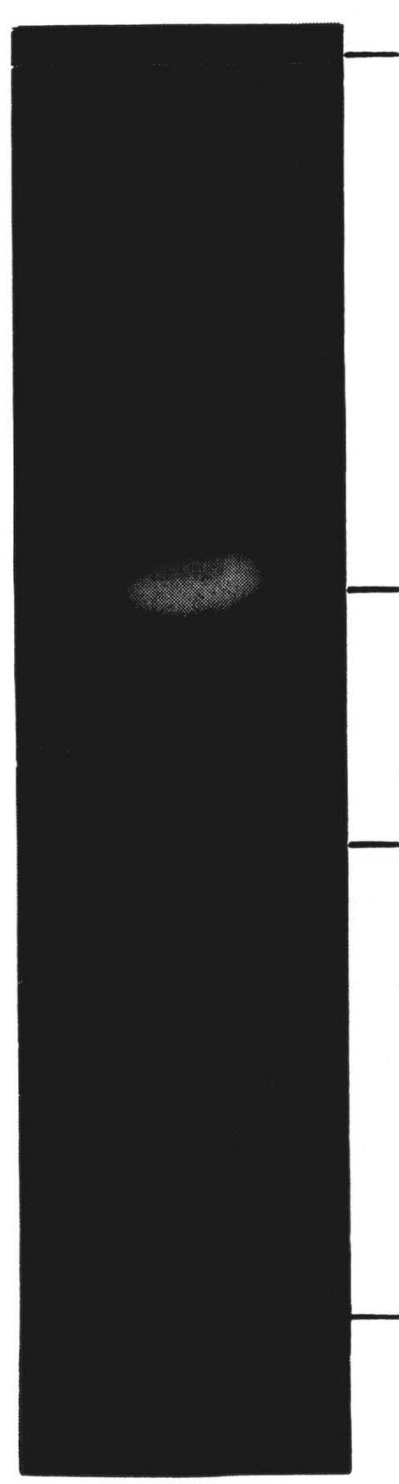

B

(Skin)

F
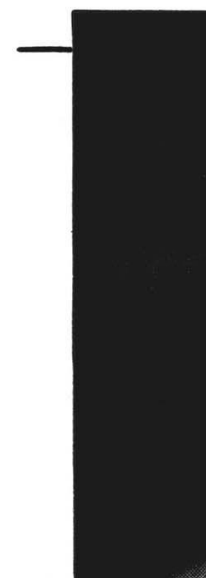

HAL

MI
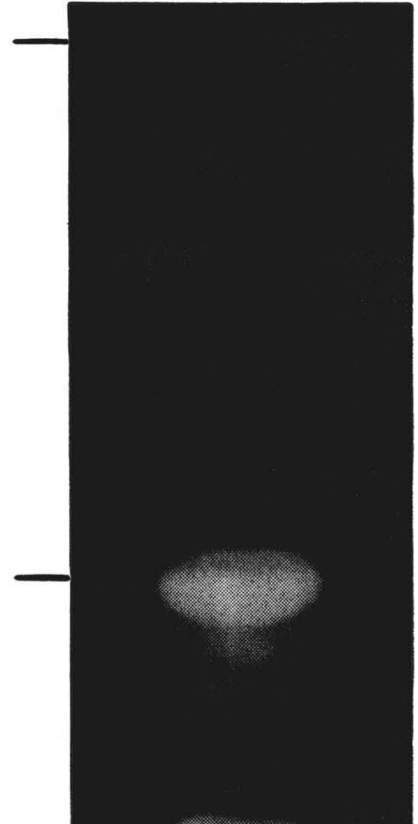

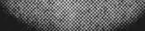

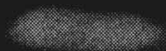
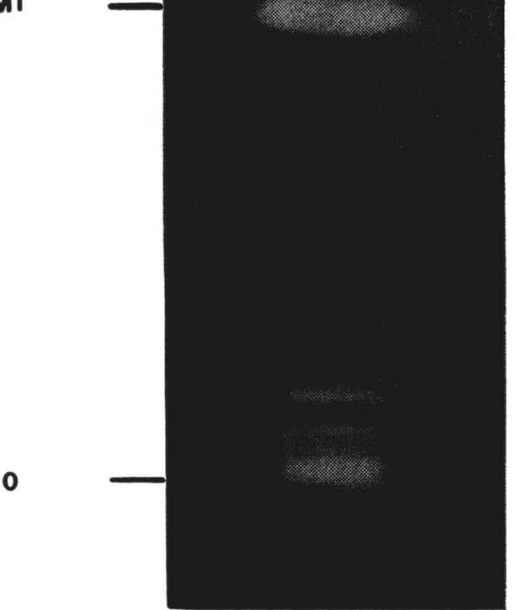

\section{Perfusion time: $60 \mathrm{~min}$}

TLC-solvent system: A

Fig. 15. Autoradiograms of ${ }^{14} \mathrm{C}-\mathrm{HAL}$ Metabolites in Prefusate (A) and Tissue (B) from the Skin Perfusion System.

\section{（b）肝灌流での代謝}

${ }^{14} \mathrm{C}-\mathrm{HAL}$ を肝臓の灌流系に添加すると, 灌流 液中の放射能の消失は速やかで, 添加後10分です でに初濃度の $10 \%$ 以下にまで減少していた。この ことは HAL の肝組織への取り込みが速やかなこ とを示している. 胆汁中への放射能の排泄は早
く, 60分ですでに添加量の $7 \%$ 以上の排泄が見ら れた。

Fig. 17 は, HAL およびその代謝物の灌流液中 での濃度变化を, 初濃度に対する\%で示したもの である。

HAL の消失に伴い, M1, M3, M4, M7, M10 


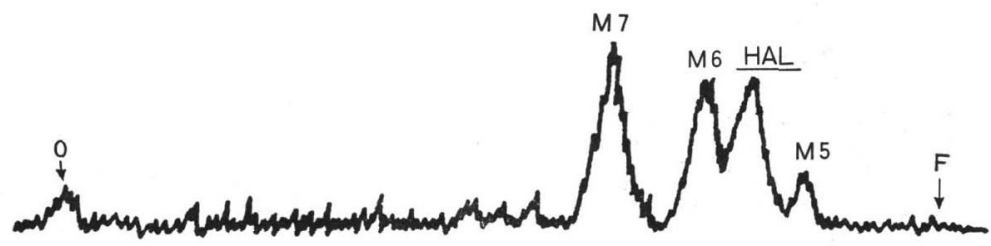

B

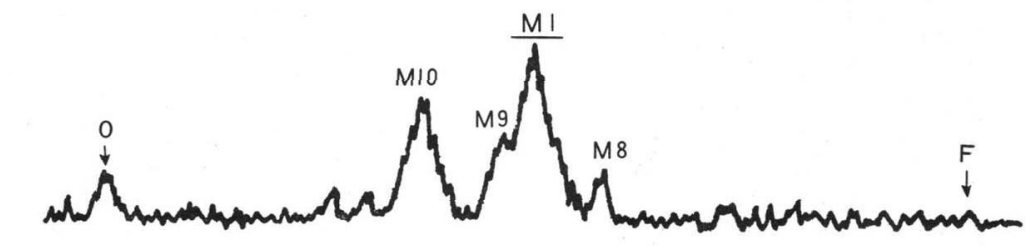

TLC-solvent system: A

Fig. 16. Actigrams of Metabolites formed after 60 min Incubation of ${ }^{14} \mathrm{C}-\mathrm{HAL}$ (A) or ${ }^{14} \mathrm{C}-\mathrm{Ml}$ (B) in Liver Homogenate.

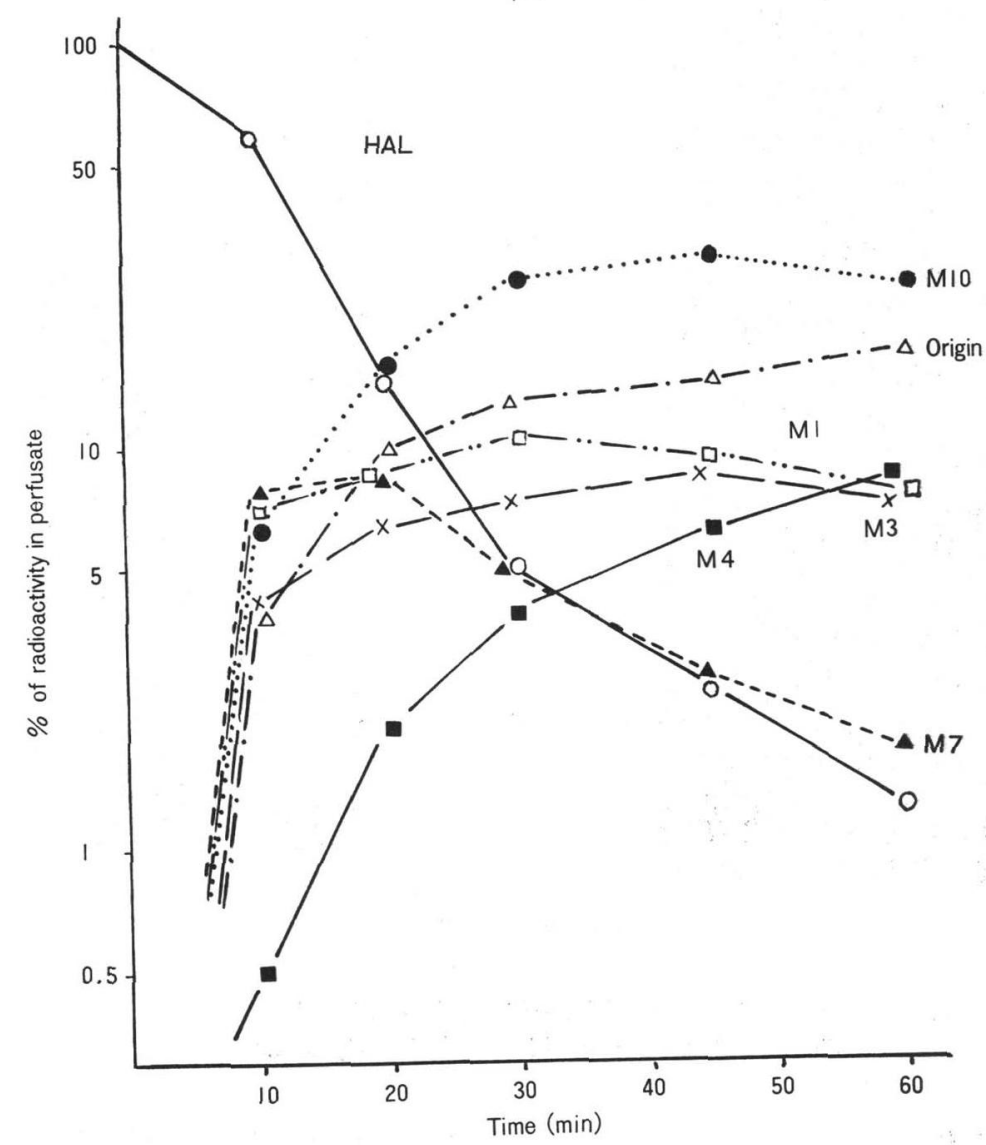

Fig. 17. HAL and its Metabolites in Perfusate from the Liver Perfusion System after Addition of ${ }^{14} \mathrm{C}-\mathrm{HAL}$.

特よび原点物質が灌流開始後速やかに生成され，

$\mathrm{M} 7$ 以外は時間とともに漸增した. $\mathrm{Cl}$ 基を有する M7は，一度急峻な生成をみたのち，速やかに消
失した。

（c）肝灌流系における H A L 代謝物の代謝 ${ }^{14} \mathrm{C}$ で標識された M1 怙よび M7 を同様に灌流 


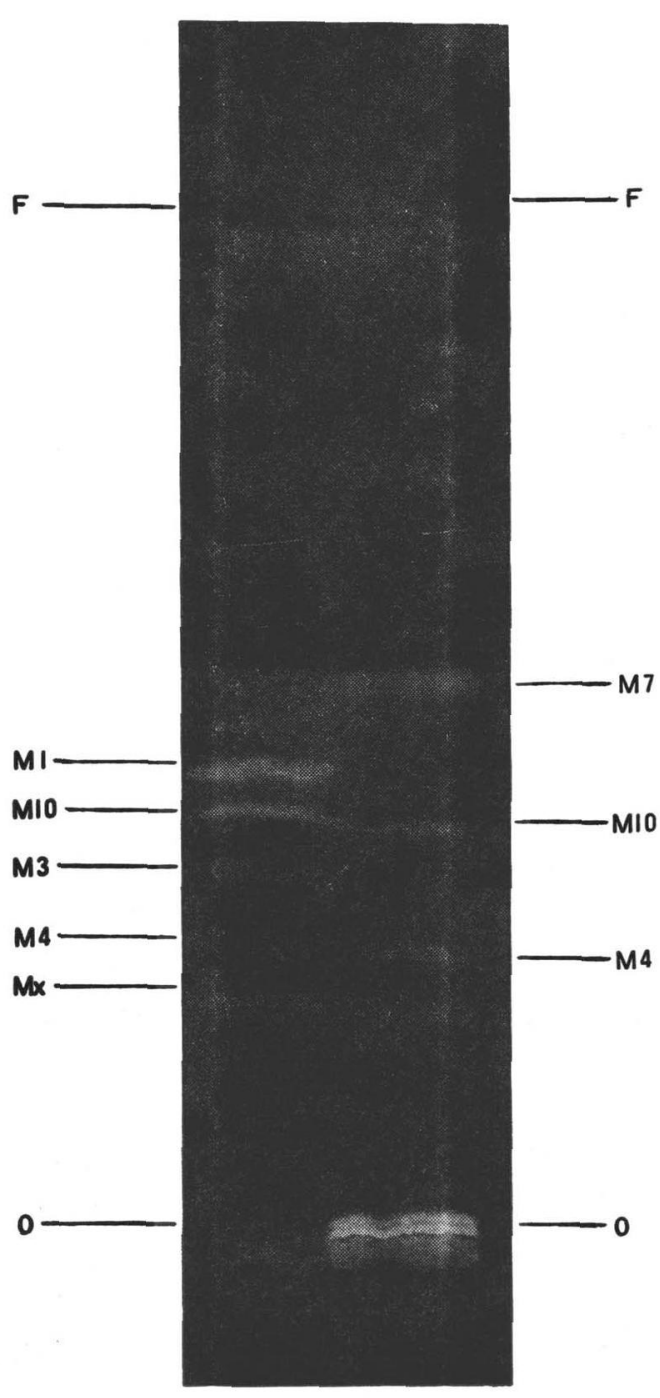

A

B

TLC-solvent system : A

Fig. 18. Autoradiograms of Metabolites in Perfusate of Liver Perfusion System at $45 \mathrm{~min}$ after Addition of ${ }^{14} \mathrm{C}-\mathrm{Ml}$ (A) or $-\mathrm{M} 7$ (B).

し, 開始後45分の TLC パターンを Fig. 18 に 示した.

$\mathrm{M} 1$ 添加時の代謝生成物を ${ }^{14} \mathrm{C}-\mathrm{HAL}$ の同時点 の結果と比較すると, M7 を除いて代謝物の種類 はほとんど共通であった.この結果は, M1 がM7 を除くその他の代謝物の前駆物質であることを示 唆するものである。また M7 からは M10，M4 が
生成することが TLC 的に確認された。

\section{3. 考 察}

ラット健常皮膚に塗布された ${ }^{14} \mathrm{C}-\mathrm{HAL}$ の放射 能は皮膚に滞留し，体内への移行はきわわてわず かであることが示された．この放射能の大部分 は, HAL 自体として存在していることから，こ の薬剂の局所消炎作用は原薬物に由来するもので あることが推測される。また，塗布後の皮膚の抽 出物中にわずかではあるが，21体- $\mathrm{OH}$ 体 (M1) の存在が示された、このことから，脱クロール反 応は皮膚組織に扮いても起こることが考光られ

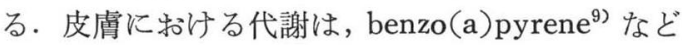
の芳香族炭化水素の酸化活性や, testosterone $\mathrm{e}^{10)}$ の還元反応などが知られているが，脱クロール反 応に関しては未知である。したがってまず，皮膚 組織に和ける M1 生成を調べるために皮膚のホモ ジネートでの脱クロール反応の有無を検討した が，代謝物の生成は認められなかった。 そこで， 皮膚灌流系での代謝を検討した。

皮䖉灌流法は, イヌについて Kjaersgaard ${ }^{11)} ら$ がすでに方法を確立しているが，ラットについて の報告は知られていない，われわれは上記の方法 をラットに適用し，灌流液中に ${ }^{14} \mathrm{C}-\mathrm{HAL}$ を加党 た場合の代謝物の生成を検討した結果, 脱クロー 几反応は intact な皮膚組織で起こることが示唆 された。

ステロイド外用薬を使用する場合の問題点は, 体内に移行した薬剤に由来する全身的副作用であ る. 皮膚に損傷を与えると体内移行量が増加する ことが知られていることから，経皮吸収後の HAL の体内での代謝を調べる必要がある. 経皮 吸収量の少ない化合物の体内運命を追跡すること はきわめて大きい困難を伴らことから，われわれ は ${ }^{14} \mathrm{C}-\mathrm{HAL}$ 静注後の体内運命を追跡することに よって経皮吸収後の HAL の代謝を推定した.

${ }^{14} \mathrm{C}-\mathrm{HAL}$ 静注後の放射能は大部分が 粪中に排 泄された，胆汁中拉よび尿中の代謝物を検索した 結果は原物質は認められず, 数種類の代謝物とし て体外に排泄されることから，このものの代謝が 速やかであることが示された. 胆汁中主代謝物は $\mathrm{M} 2$ であることから, HAL $\rightarrow \mathrm{M} 1 \rightarrow \mathrm{M} 2$ といら主 代謝経路の存在が推定された.この結果は Kripa- 


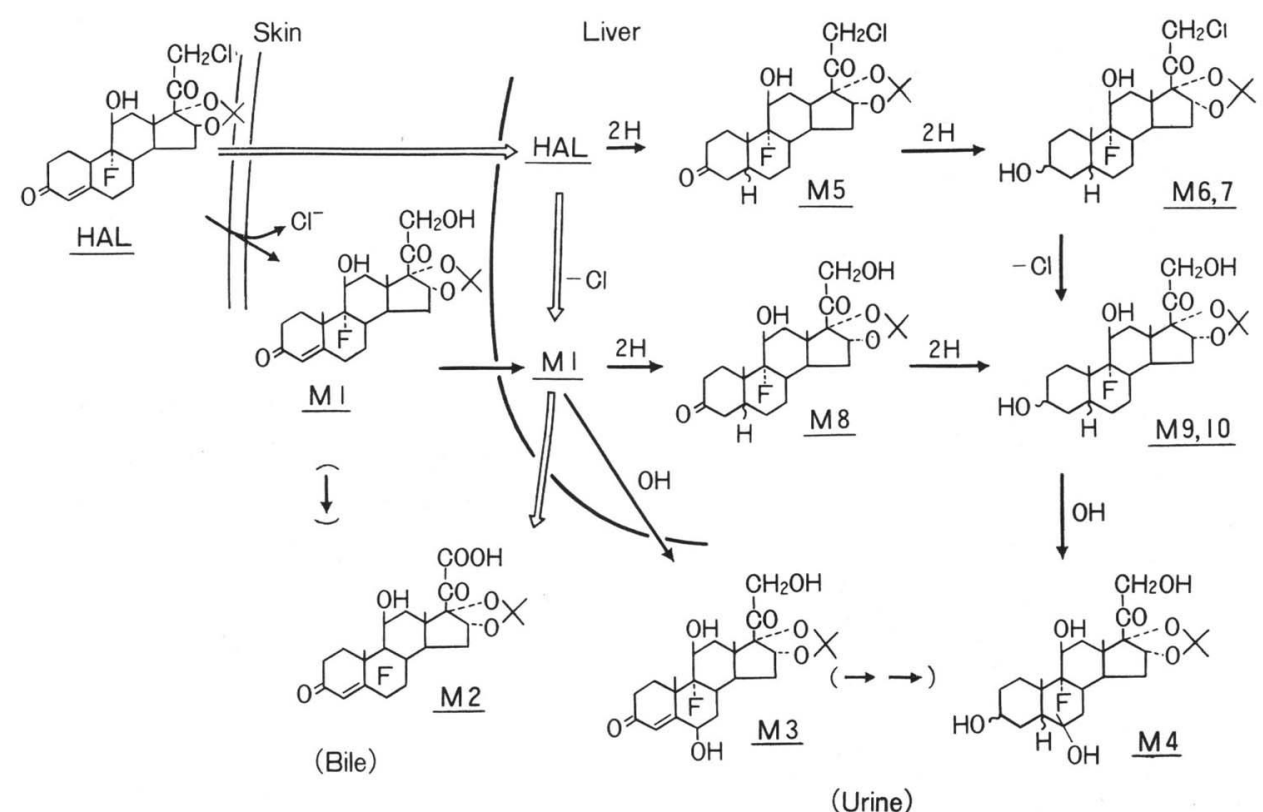

Fig. 19. Tentatively Proposed Metabolic Pothway of HAL in Rats.

lani ${ }^{12)}$ らのイヌ胆汁中代謝物と一致し, また Bradlow ${ }^{13)}$ らのhydrocortisone のヒトでの主代謝物 が21位-COOH 体であったことと一致する.

ステロイド系抗炎症薬の代謝は, 主として肝蔵 で行われることが知られている ${ }^{8)}$. 肝蔵の灌流系 で HAL の代謝を調べた結果, HAL は速やかに 灌流液から消失し, 最初の主なステップとして脱 クロル反応をらけて M1 となり，M2 に至るほか， 一部は M1 から M3，M4 至る系が確認された。 また M7 が明らかに生成されたことは必ずしもす べての代謝物が M1を経由するものではなく, 脱 クロル反応をうける以前に $\Delta^{4}$ 和よび 3 位ケト基 が還元される代謝経路の存在することを示唆して いる.

以上の結果から, HAL の経皮吸収後の代謝経 路を Fig. 19 のように推定した.

HAL を皮膚に塗布すると，一部は皮膚で代謝
をうけるが，大部分はHAL として皮膚に滞留す る、一部は循環血液中に移行するが，その大部分 は HAL である。体内に移行した HAL は肝臓 に移行し, 脱クロル化され, さらにM2になり, 胆汁から排泄される。また一部は M3 となって尿 中に排泄される. 以上が経皮吸収後の HAL の主 代謝経路と考学られるが，その他にも一部分が脱 クロルされる前に還元反応をらけて $55 \rightarrow \mathrm{M} 7 \rightarrow \mathrm{M}$ $10 \rightarrow \mathrm{M} 4$ の経路で尿中に排泄されることが示され た. 主代謝中間体 M1 の薬理作用は, 三坂らの予 備的検討 (私信) に上ると原薬物の $1 / 3$ であると いら．また M 2 は $\mathrm{COOH}$ 体であることから容易 に体外に排泄されるものと考えられる ${ }^{14)}$. このよ らに体内に吸収された HAL が速やかに排泄また は代謝的不活性化を受けることは, HAL が強い 局所作用を持つにもかかわらず全身作用が弱い事 実と一致する.

\section{文献}

1) F.K. Bagatell ; Halcinonide : a new potent topical anti-inflammatory drug. Cutis, $14: 459-462$ (1974).

2）三坂英一, 飯塚義夫, 堀越大能, 山口 武, 小島高義, 遠藤陽子, 三沢由美子, 角田 博子, 馬場義彦, 田中喜一郎 ; 外用ステロイド halcinonide の抗炎症作用. 応用薬 理, 19:75-82 (1980).

3) P. Egli ; Synthesis of halcinonide- ${ }^{14} \mathrm{C}$, Squibb's report (1979). 
4) 中島栄一, 繁原英治, 西垣 隆, 宮越 宏, 堀口正明, 林了三, 田中 実; 抗炎症 性ステロイド，ハルシノナイドの代謝研究，第10回薬物代謝と薬効一毒性シンポジウ 么要旨集, p.93 (昭和53年).

5）清水康之, 薮田良子, 島雄周平, 中島栄一, 田中 実; Halcinonide ${ }^{-14} \mathrm{C}$ の経皮吸収 後の体内分布について。 日皮会誌, $90: 1113-1120$ (1980).

6) J. Garb ; Nevus verrucosus unilateris cured with podophyllin ointment. Arch. Dermatol., $81: 606-609$ (1960).

7）田中 実, 服部建治 ; 肝灌流実験法. 酵素誘導, p. 248-253（高畑英伍，佐藤哲男監 修, 清至書院, 1985).

8）岡田弘二;アンドロゲン，エストロゲン，プロゲスチンの体内動態と投与法. 日本臨 床, $36: 308-313$ (1978).

9) W. Levin, A.H. Conney, A.P. Alvares, I. Merkatz and A. Kappas ; Induction of benzo (a) pyrene hydroxylase in human skin. Science, $176: 419-420$ (1972).

10) V.H. Price; Testosterone metabolism in the skin. Arch. Dermatol., $111: 1496-$ 1502 (1975).

11) A.R. Kjaersgaard ; Perfusion of isolated dog skin. J. Invest. Dermatol., $22: 135$ -141 (1954).

12) K.J. Kripalani, A. Zein El-Abdin, A. Dean and A.I. Cohen ; Biotransformation of halcinonide in dog. Pharmacologist, $19: 240$ (1977).

13) H.L. Bradlow, B. Zumoff, J. Lee and L. Hellan; Isolation and identification of four new carboxylic acid metabolites of cortisol in man. J. Clin. Endocrinol. Metab., 37 : 811-818 (1973).

14) S. Gordon and J. Morrison; The metabolic fate of triamcinoline acetonide in laboratory animals. Steroids, $32: 25-35$ (1978). 